\title{
Peak Detection Control Strategy based STATCOM for Suppression of Power Quality Problems
}

\author{
$J$. Bangarraju ${ }^{1}, V$. Rajagopal $^{2}, V$. Sharada $^{2}$ and $K$. Lakshmaiah $^{3}$ \\ ${ }^{1}$ B V Raju Institute of Technology, Narsapur, Medak, Telangana, India \\ ${ }^{2}$ Stanley College of Engineering and Technology for Women, Hyderabad, Telangana, India \\ ${ }^{3}$ I\&CAD Department, Warangal, Telangana, India
}

\begin{abstract}
This paper explains about control of VSC using uni-polar switching based Static Compensator (STATCOM) using Peak Detection Control Strategy for elimination of PQ Problems. The proposed STATCOM are operated in PFC (Power Factor Correction) mode and ZVR (Zero Voltage Regulation) mode. Under these operation modes of STATCOM is able to suppression of harmonics, PFC at source, reactive power compensation, load balancing and compensation of neutral current. A non-isolated star/three individual singlephase transformers are connected at PCC (Point of Common Coupling) to mitigate neutral current. The Peak Detection Control Strategy is simple to implement for estimating switching pulses for VSC. This peak detection control strategy based STATCOM is modelled, simulated results are validated using MATLAB R2013b.
\end{abstract}

\section{Introduction}

Recent years Power Distribution Network (PDN) suffering from high neutral current, reactive power burden, waveform distortion and load balancing are main PQ problems. These PQ problems are primarily occurs due to non-linear loads, lagging power factor balanced or unbalanced loads etc. These PQ (Power Quality) problems are mitigated using advancement of active compensators [1]-[2]. The different topologies modeling and design analysis of active compensator are discussed [3]-[4].To maintain balance supply currents in 3-phase 4wire system, mitigation of neutral current and its control are necessary for maintaining balanced source currents. Different transformer connections such as T-Connection, Scott Connection, Star-delta, Star-Hexagon, Zig-Zag transformer etc based STATCOM are used for neutral current compensation [5]-[7].This proposed star/three single phase transformer configuration will reduce rating of VSC. The performance of STATCOM very much depends on control strategy and proposed transformer also reduce size of STATCOM. The d-q and p-q method based control strategies are used for harmonics estimation without estimating separate components which reduces calculation burden [8]. A application of non-linear robust control strategy and mathematical for active filters [9]. A review on different control algorithms to APFs (Active Power Filters) and different performance strategies are compared [10]. The control algorithms are I- $\Phi$ p-q theory,
Instantaneous Reactive Power Theory, Integral generalized control staretgy, Synchronous Reference Frame Theory, and adaptive control startegies [11].In general, the performance analysis and design of STATCOM are observed based on IEC and IEEE standards [12]-[13].

The preset day improvement of shunt APFs are considered as STATCOM to mitigate current related PQ problems. The mathematical analysis of STATCOM using '-' sequence component. The analysis of zero and '-' sequence component of voltage estimation elimination of current sensors using balanced theory [14]-[15].

The peak detection control strategy is implemented using MATLAB R2013b for suppression of harmonics, PFC at source, reactive power control, load balancing and mitigate neutral current.

\section{Design and Analysis of STATCOM}

The basic schematic diagram of six-leg STATCOM is connected to 3- $\Phi$ AC supply with an impedance of $\left(Z_{s}\right)$ is depicted in Fig.1. In this system configuration, the main feature of six leg of VSC is to doubles switching of waveform which reduce filter circuit requirement. For design and implementation of peak detection control algorithm, sensed AC mains phase voltage variables are $\left(\mathrm{v}_{\mathrm{sa}}, \mathrm{v}_{\mathrm{sb}}, \mathrm{v}_{\mathrm{sc}}\right), \mathrm{AC}$ mains currents $\left(\mathrm{i}_{\mathrm{sa}}, \mathrm{i}_{\mathrm{sb}}, \mathrm{i}_{\mathrm{sc}}\right)$, distribution load currents $\left(\mathrm{i}_{\mathrm{La}}, \mathrm{i}_{\mathrm{Lb}}, \mathrm{i}_{\mathrm{Lc}}\right)$ and DC bus voltage $\left(\mathrm{v}_{\mathrm{dc}}\right)$. A sixleg VSC is connected to one interfacing inductor $\left(\mathrm{L}_{\mathrm{f}}\right)$ at each leg of VSC. Interfacing inductor voltage drop and DC bus voltage are dependent on each other. The interfacing 
inductor voltage drop must be less than $8 \%$ of rated value for successful operation.

A series connected R-C passive filter $\left(R_{f}\right.$ and $\left.C_{f}\right)$ is installed at PCC (Point of Common Coupling), which is used to mitigate high frequency noise switching at PCC. The compensating currents $\left(i_{c a}, i_{c b}, i_{c c}\right)$ are injected by proposed STATCOM to suppression of PQ problems. The IGBT switches rating is selected in VSC is based on compensation of STATCOM.

\section{Peak Detection Control Strategy}

A block diagram of Peak detection control strategy is shown in Fig. 1. It is implemented on a six-leg VSC based STATCOM for PQ improvement. The proposed peak detection control algorithm is robust and it can easily reduce harmonic distortion at the source. The basic equations of peak detection control strategy for generation of different control signals are given.

\section{A. Estimation of In-Phase Unit Vectors and Amplitude of PCC Voltage}

The in-phase unit vector components and magnitude of PCC voltages $\left(V_{t p}\right)$ of distribution system and are determined as

$v_{t p}=\sqrt{\left\{2 / 3\left(v_{s a}^{2}+v_{s b}^{2}+v_{s c}^{2}\right)\right\}}$

The three phase voltages $\left(\mathrm{V}_{\mathrm{sa}}, \mathrm{V}_{\mathrm{sb}}, \mathrm{V}_{\mathrm{sc}}\right)$ are at the PCC.

The in-phase unit vector components of PCC voltages $\left(\mathrm{u}_{\mathrm{ia}}, \mathrm{u}_{\mathrm{ib}}\right.$ and $\left.\mathrm{u}_{\mathrm{ic}}\right)$ are determined as

$u_{i a}=v_{s a} / v_{t p} ; u_{i b}=v_{s b} / v_{t p} ; u_{i c}=v_{s c} / v_{t p} ;$

The quadrature phase unit vectors ( $\mathrm{u}_{\mathrm{qa}}, \mathrm{u}_{\mathrm{qb}}$ and $\mathrm{u}_{\mathrm{qc}}$ ) are determined using in-phase unit vectors $\left(\mathrm{u}_{\mathrm{ia}}, \mathrm{u}_{\mathrm{ib}}\right.$ and $\left.\mathrm{u}_{\mathrm{ic}}\right)$ as

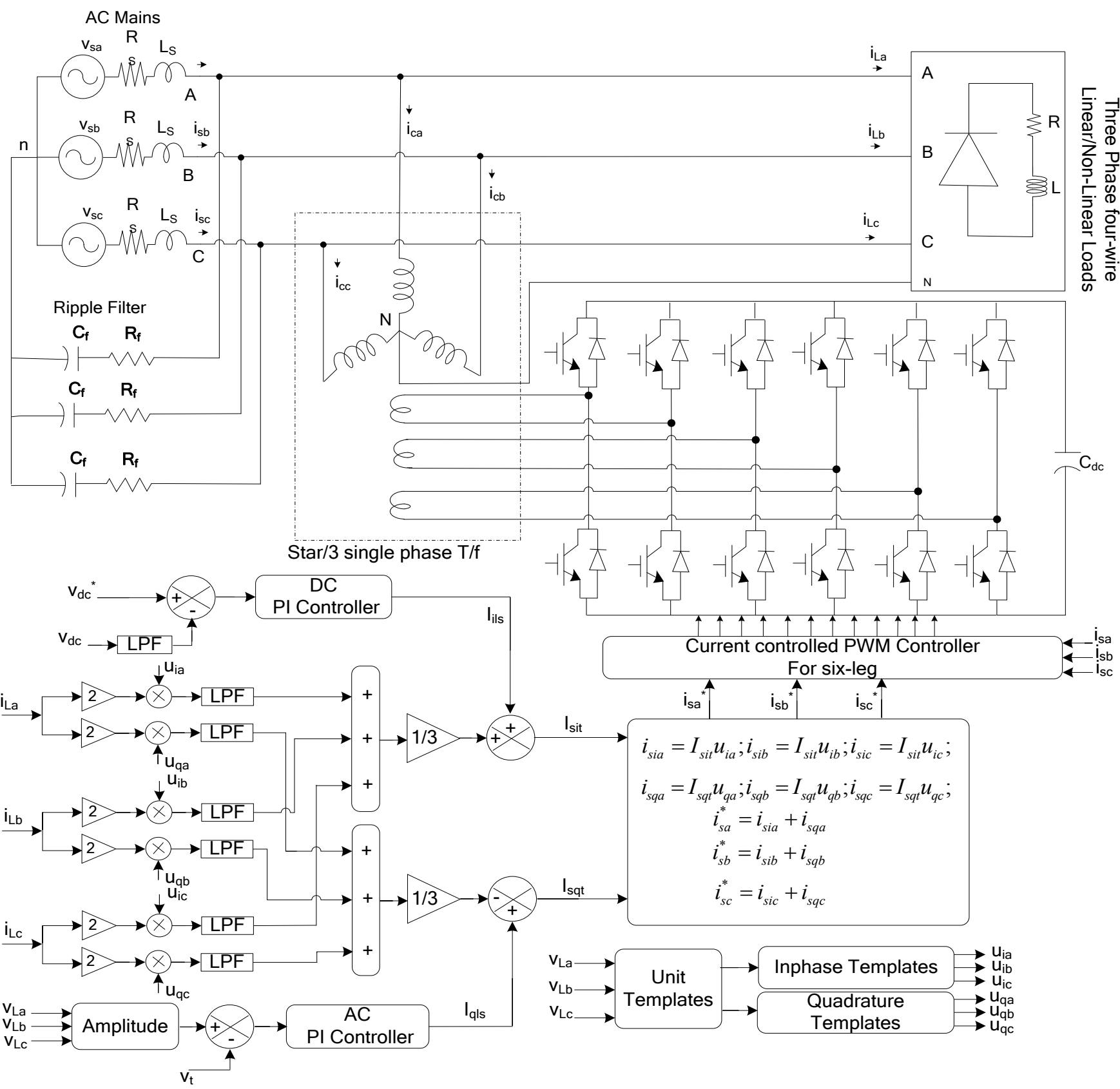

Fig.1. Schematic diagram of peak detection control strategy based STATCOM 


$$
\begin{aligned}
& u_{q a}=\left(-u_{i b}+u_{i c}\right) / \sqrt{3} \\
& u_{q b}=\left(3 u_{i a}+u_{i b}-u_{i c}\right) / 2 \sqrt{3} \\
& u_{q c}=\left(-3 u_{i a}+u_{i b}-u_{i c}\right) / 2 \sqrt{3}
\end{aligned}
$$

B. Active and reactive power component of load current Estimation

In General, the distribution load current (iL) is distorted and lagging because of application of highly non-linear and reactive loads. These distribution load current can be express as

$$
i_{L a}(t)=I_{d c}+I_{L i a}+I_{L q a}+I_{h d}
$$

Where $I_{d c}$ is the DC component magnitude of load current and this is very small because of load current waveform is half wave symmetry. Where $\mathrm{I}_{\text {Lia }}$ and $\mathrm{I}_{\mathrm{Lqa}}$ are the ' $a$ ' phase fundamental active and reactive power component of load current. The $I_{\text {hd }}$ is corresponding to load current harmonics of $\mathrm{i}_{\text {La. }}$.

Equation (6) can be represented as

$$
\begin{aligned}
& i_{L a}(t)=I_{d c}+I_{L i a} \sin \omega t+I_{L q a} \cos \omega t \\
& +\sum_{n=1}^{\infty} I_{2 k} \sin \left(2 \omega \mathrm{kt}+\Phi_{2 k}\right) \\
& \left.+\sum_{m=1}^{\infty} I_{2 m+1} \sin \left\{(2 m+1) \omega \mathrm{t}+\Phi_{2 m+1}\right)\right\}
\end{aligned}
$$

To extract peak magnitude of phase 'a' fundamental active power component of load current $\left(\mathrm{I}_{\mathrm{Lia}}\right)$. The ' $\mathrm{a}$ ' phase load current $\left(i_{\text {La }}\right)$ is multiplied with in-phase unit vector $\mathrm{u}_{\mathrm{ia}}(\sin \omega \mathrm{t})[16]$.

$i_{L i a}=i_{L a}(t) \cdot u_{i a}=i_{L a}(t) \cdot \sin \omega t$

$=I_{d c} \sin \omega t+\left[\left(I_{\text {Lia }} / 2\right)\{1-\cos 2 \omega t\}\right]+\left[\left(I_{\text {Lqa }} / 2\right)\{\sin \omega t\}\right]$

$+\sum_{k=1}^{\infty} \frac{I_{2 k}}{2}\left[\cos \left\{(2 k-1) \omega t+\Phi_{2 k}\right\}-\cos \left\{(2 k+1) \omega t+\Phi_{2 k}\right\}\right]$

$+\sum_{m=1}^{\infty} \frac{I_{2 m+1}}{2}\left[\cos \left\{(2 m \omega t)+\Phi_{2 m+1}\right\}-\cos \left\{(2 m+2) \omega t+\Phi_{2 m+1}\right\}\right]$

From the equation (8) it is clear that $i_{\text {Lia }}$ consists of DC component and oscillatory components. The $i_{L i a}$ is proportional to $\mathrm{I}_{\mathrm{Lia}} / 2$. A LPF with cut-off frequency $\left(\mathrm{f}_{\mathrm{c}}\right)$ not more $15 \mathrm{~Hz}$ is used to extract magnitude of fundamental active power component load current and also gain factor of ' 2 ' is used to determine $\left(\mathrm{I}_{\mathrm{Lia}}\right.$ '). Similar procedure is used to extract ' $b$ and c' phase fundamental active power component load currents ( $\mathrm{I}_{\mathrm{Lib}}{ }^{\prime}$ and $\left.\mathrm{I}_{\mathrm{Lic}}{ }^{\prime}\right)$. The average magnitude of fundamental active power component of load currents $\left(\mathrm{I}_{\mathrm{LiA}}\right)$ is estimated as

$$
I_{\text {LiA }}=\left(I_{L i a}^{\prime}+I_{L i b}^{\prime}+I_{L i c}^{\prime}\right) / 3
$$

To extract peak magnitude of phase ' $a$ ' fundamental reactive power component of load current $\left(\mathrm{I}_{\mathrm{Lqa}}\right)$. The ' $\mathrm{a}$ ' phase load current ( $\mathrm{i}_{\mathrm{La}}$ ) is multiplied with quadraturephase unit vector $\mathrm{u}_{\mathrm{qa}}(\cos \omega \mathrm{t})$

$$
\begin{aligned}
& i_{L q a}=i_{L a}(t) \cdot u_{q a}=i_{L a}(t) \cdot \cos \omega t \\
& =I_{d c} \cos \omega t+\left[\left(I_{\text {Lqa }} / 2\right)\{1+\cos 2 \omega t\}\right]+\left[\left(I_{\text {Lia }} / 2\right)\{\sin \omega t\}\right] \\
& +\sum_{k=1}^{\infty} \frac{I_{2 k}}{2}\left[\sin \left\{(2 k+1) \omega t+\Phi_{2 k}\right\}+\sin \left\{(2 k-1) \omega t+\Phi_{2 k}\right\}\right] \\
& +\sum_{m=1}^{\infty} \frac{I_{2 m+1}}{2}\left[\sin \left\{(2 m+2) w t+\Phi_{2 m+1}\right\}+\sin \left\{(2 m) \omega t+\Phi_{2 m+1}\right\}\right]
\end{aligned}
$$

From the equation (11) it is clear that $i_{\text {Lqa }}$ consists of DC component and oscillatory components. The $\mathrm{i}_{\mathrm{Lqa}}$ is proportional to $\mathrm{I}_{\mathrm{Lqa}} / 2$. A LPF with cut-off frequency $\left(\mathrm{f}_{\mathrm{c}}\right)$ not more $15 \mathrm{~Hz}$ is used to extract magnitude of fundamental reactive power component load current and also gain factor of ' 2 ' ' is used to determine $\left(\mathrm{I}_{\mathrm{Lqa}}\right.$ '). Similar procedure is used to extract ' $b$ and c' phase fundamental reactive power component load currents ( $\mathrm{I}_{\mathrm{Lqb}}$ ' and $\left.\left.\mathrm{I}_{\text {Lqc }}\right)^{\prime}\right)$. The average magnitude of fundamental reactive power component of load currents $\left(\mathrm{I}_{\mathrm{LqA}}\right)$ is estimated as

$I_{L q A}=\left(I_{L q a}^{\prime}+I_{L q b}^{\prime}+I_{L q c}^{\prime}\right) / 3$

C. Active and Reactive power component of reference source current estimation

A small active power flows in to DC bus capacitor of VSC for control of DC bus voltage of STATCOM. The current required for DC bus VSC is extracted using DC bus PI controller to eliminate steady state error.

$$
I_{i l s}(k)=I_{i l s}(k-1)+\mathrm{K}_{\mathrm{ip}}\left\{V_{e d}(k)-V_{e d}(k-1)\right\}+K_{\mathrm{ii}} V_{e d}(k)
$$

Where $V_{\text {ed }}=-V_{d c}+V_{d c}{ }^{*}$ is the voltage error in DC bus. $V_{d c}$ and $\mathrm{V}_{\mathrm{dc}}{ }^{*}$ are sensed filtered voltage and reference voltage of DC bus of capacitor based STATCOM. The DC bus PI controllers gain constants $\left(\mathrm{K}_{\mathrm{ip}}\right.$ and $\left.\mathrm{K}_{\mathrm{ii}}\right)$.

The active power component of source current $\left(\mathrm{I}_{\text {sit }}\right)$ is sum of average magnitude fundamental active power component of load current $\left(\mathrm{I}_{\mathrm{LiA}}\right)$ and required current for DC bus of STATCOM $\left(\mathrm{I}_{\mathrm{ils}}\right)$.

$I_{\text {sit }}=I_{\text {LiA }}+I_{i l s}$

The proposed STATCOM can be operated in PFC or ZVR modes. The PCC voltage may increase or decrease from rated voltage based on loading. In ZVR mode, the PCC voltage is maintained to rated voltage by supplying additional reactive power. An AC bus PI controller is used to determine reactive power component to be supplied in ZVR mode of STATCOM. The extra component of reactive power of source current required for ZVR is given by output of AC bus PI controller.

$I_{q l s}(k)=I_{q l s}(k-1)+\mathrm{K}_{q p}\left\{V_{t p e}(k)-V_{t p e}(k-1)\right\}+K_{\mathrm{qi}} V_{t p e}(k)$

Where $\mathrm{V}_{\mathrm{tpe}}=-\mathrm{V}_{\mathrm{tp}}+\mathrm{V}_{\mathrm{tp}}{ }^{*}$ is the voltage error magnitude in AC bus. $V_{\text {tp }}$ and $V_{\text {tp }}{ }^{*}$ are sensed magnitude of PCC voltage and reference PCC voltage. The AC bus PI controllers 
gain constants $\left(\mathrm{K}_{\mathrm{qp}}\right.$ and $\left.\mathrm{K}_{\mathrm{qi}}\right)$. The average magnitude fundamental reactive power component of load current $\left(\mathrm{I}_{\mathrm{LqA}}\right)$ is subtracted from output of $\mathrm{AC}$ bus PI controller $\left(\mathrm{I}_{\mathrm{qls}}\right)$ to estimate total reactive power component of source current $\left(\mathrm{I}_{\mathrm{sqt}}\right)$

$$
I_{s q t}=-I_{L q A}+I_{q l s}
$$

D. Reference supply currents estimation and estimation of switching pulses

Using active power component of source current $\left(\mathrm{I}_{\text {sit }}\right)$ and in- phase unit vector components $\left(\mathrm{u}_{\mathrm{ia}}, \mathrm{u}_{\mathrm{ib}}\right.$ and $\left.\mathrm{u}_{\mathrm{ic}}\right)$ are used to estimate reference active power components of supply currents $\left(\mathrm{i}_{\text {sia }}, \mathrm{i}_{\text {sib }}, \mathrm{i}_{\text {sic }}\right)$

$$
i_{\text {sia }}=I_{s i t} u_{i a} ; i_{s i b}=I_{s i t} u_{i b} ; i_{\text {sic }}=I_{s i t} u_{i c} \text {; }
$$

Similarly, Using reactive power component of source current $\left(\mathrm{I}_{\mathrm{sqt}}\right)$ and quadrature- phase unit vector components ( $\mathrm{u}_{\mathrm{qa}}, \mathrm{u}_{\mathrm{qb}}$ and $\mathrm{u}_{\mathrm{qc}}$ ) are used to estimate reference reactive power components of supply currents ( $\left.\mathrm{i}_{\text {sqa }}, \mathrm{i}_{\text {sqb }}, \mathrm{i}_{\text {sqc }}\right)$

$i_{s q a}=I_{s q t} u_{q a} ; i_{s q b}=I_{s q t} u_{q b} ; i_{s q c}=I_{s q t} u_{q c} ;$

The total reference supply currents $\left(\mathrm{i}_{\mathrm{sa}}{ }^{*}, \mathrm{i}_{\mathrm{sb}}{ }^{*}, \mathrm{i}_{\mathrm{sc}}{ }^{*}\right)$ are obtained sum of reference active powers components of supply currents $\left(i_{\text {sia, }} i_{\text {sib, }} i_{\text {sic }}\right)$ and reactive powers components of supply currents $\left(\mathrm{i}_{\text {sqa }}, \mathrm{i}_{\mathrm{sqb}}, \mathrm{i}_{\mathrm{sqc}}\right)$

$i_{s a}^{*}=i_{s i a}+i_{s q a}$

$i_{s b}^{*}=i_{s i b}+i_{s q b}$

$i_{s c}^{*}=i_{s i c}+i_{s q c}$

\section{Results and Discussion}

The performance of peak detection control strategy based STATCOM simulated using MATLAB R2013b under SIMULINK. The proposed STATCOM is operated unipolar switching to validate dynamic and steady state performance under PFC and ZVR modes in MATLAB.

\section{A. Response of peak detection control strategy based STATCOM under linear load in PFC mode}

The response of peak detection control strategy based STATCOM is studied in PFC mode at linear loads is shown in Fig.2. The response of PDN parameters are presented in Fig.2 in terms of source voltage $\left(\mathrm{v}_{\text {sabc }}\right)$, balanced source current $\left(i_{\text {sabc }}\right)$, load current ( $\left.i_{\text {Labc }}\right)$, STATCOM injecting current $\left(\mathrm{i}_{\text {cabc }}\right)$, load neutral current of $\operatorname{PDN}\left(\mathrm{i}_{\text {Ln }}\right)$,source neutral current $\left(\mathrm{i}_{\mathrm{sn}}\right)$, dc bus voltage magnitude $\left(\mathrm{V}_{\mathrm{dc}}\right)$ and amplitude of terminal voltage $\left(\mathrm{v}_{\mathrm{tp}}\right)$ under uni-polar switching operations of STATCOM. Upto $\mathrm{t}=0.8 \mathrm{sec}$, it was clearly observed from Fig. 2 that the source voltage $\left(\mathrm{v}_{\mathrm{sabc}}\right)$ and source current $\left(\mathrm{i}_{\mathrm{sabc}}\right)$ are highly balanced, free from harmonics, the angle between

source voltage and source current is zero, source neutral current is maintained to zero. At $\mathrm{t}=0.8 \mathrm{sec}$, one phase is suddenly removed but response parameters of PDN shows highly balanced, free from harmonics, the angle between source voltage and source current is zero, source neutral current is maintained to zero. Again at $\mathrm{t}=0.9 \mathrm{sec}$, disconnected one phase reapplied, it was observed same. The amplitude of DC bus voltage $\left(\mathrm{v}_{\mathrm{dc}}\right)$ and amplitude of terminal voltage $\left(\mathrm{v}_{\mathrm{tp}}\right)$ are maintained at $400 \mathrm{~V}$ and $320 \mathrm{~V}$ in Fig.2 .

B. Response of peak detection control strategy based STATCOM under linear load in ZVR mode

The response of peak detection control strategy based STATCOM is discussed in ZVR mode at linear loads is depicted in Fig.3. The response of PDN parameters are discussed in Fig.3 in terms of source voltage $\left(\mathrm{v}_{\mathrm{sabc}}\right)$, balanced source current $\left(i_{\text {sabc }}\right)$, load current ( $\left.i_{\text {Labc }}\right)$, STATCOM injecting current $\left(i_{\text {cabc }}\right)$, load neutral current of $\operatorname{PDN}\left(\mathrm{i}_{\text {Ln }}\right)$, source neutral current $\left(\mathrm{i}_{\mathrm{sn}}\right)$, dc bus voltage magnitude $\left(\mathrm{V}_{\mathrm{dc}}\right)$ and amplitude of terminal voltage $\left(\mathrm{V}_{\mathrm{tp}}\right)$ under uni-polar switching operations of STATCOM. Up to $\mathrm{t}=0.8 \mathrm{sec}$, it was clearly observed from Fig. 3 that the source voltage $\left(\mathrm{v}_{\mathrm{sabc}}\right)$ and source current $\left(\mathrm{i}_{\mathrm{sabc}}\right)$ are highly balanced, free from harmonics, reactive power control, source neutral current is maintained to zero. At $\mathrm{t}=0.8 \mathrm{sec}$, one phase is suddenly removed but response parameters of PDN shows highly balanced, free from harmonics, reactive power control, source neutral current is maintained to zero. Again at $\mathrm{t}=0.9 \mathrm{sec}$, disconnected one phase reapplied, it was observed same. The amplitude of DC bus voltage $\left(\mathrm{v}_{\mathrm{dc}}\right)$ and amplitude of terminal voltage $\left(\mathrm{v}_{\mathrm{tp}}\right)$ are maintained at $400 \mathrm{~V}$ and $339 \mathrm{~V}$ in Fig.3.
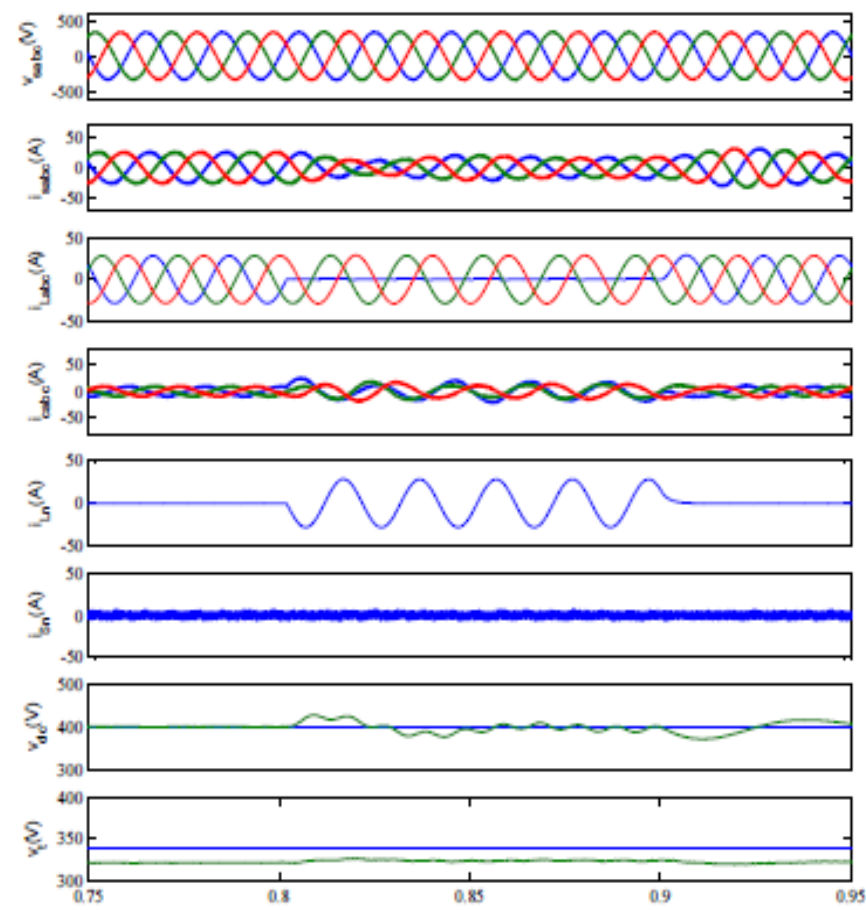

Fig.2 Response of peak detection control strategy based STATCOM under linear loads in PFC mode

C. Response of peak detection control strategy based STATCOM under non-linear load in PFC mode

The response of peak detection control strategy based STATCOM is studied in PFC mode at non-linear loads is shown in Fig.4. The response of PDN parameters are presented in Fig. 4 in terms of source voltage $\left(\mathrm{v}_{\text {sabc }}\right)$, balanced source current $\left(i_{\text {sabc }}\right)$, load current ( $\left.i_{\text {Labc }}\right)$, STATCOM injecting current $\left(i_{\text {cabc }}\right)$, load neutral current of $\operatorname{PDN}\left(\mathrm{i}_{\mathrm{Ln}}\right)$, source neutral current $\left(\mathrm{i}_{\mathrm{sn}}\right)$, dc bus voltage magnitude $\left(\mathrm{V}_{\mathrm{dc}}\right)$ and amplitude of terminal voltage $\left(\mathrm{v}_{\mathrm{tp}}\right)$ 
under uni-polar switching operations of STATCOM. Up to $\mathrm{t}=0.8 \mathrm{sec}$, it was clearly observed from Fig. 4 that the source voltage $\left(\mathrm{v}_{\mathrm{sabc}}\right)$ and source current $\left(\mathrm{i}_{\mathrm{sabc}}\right)$ are
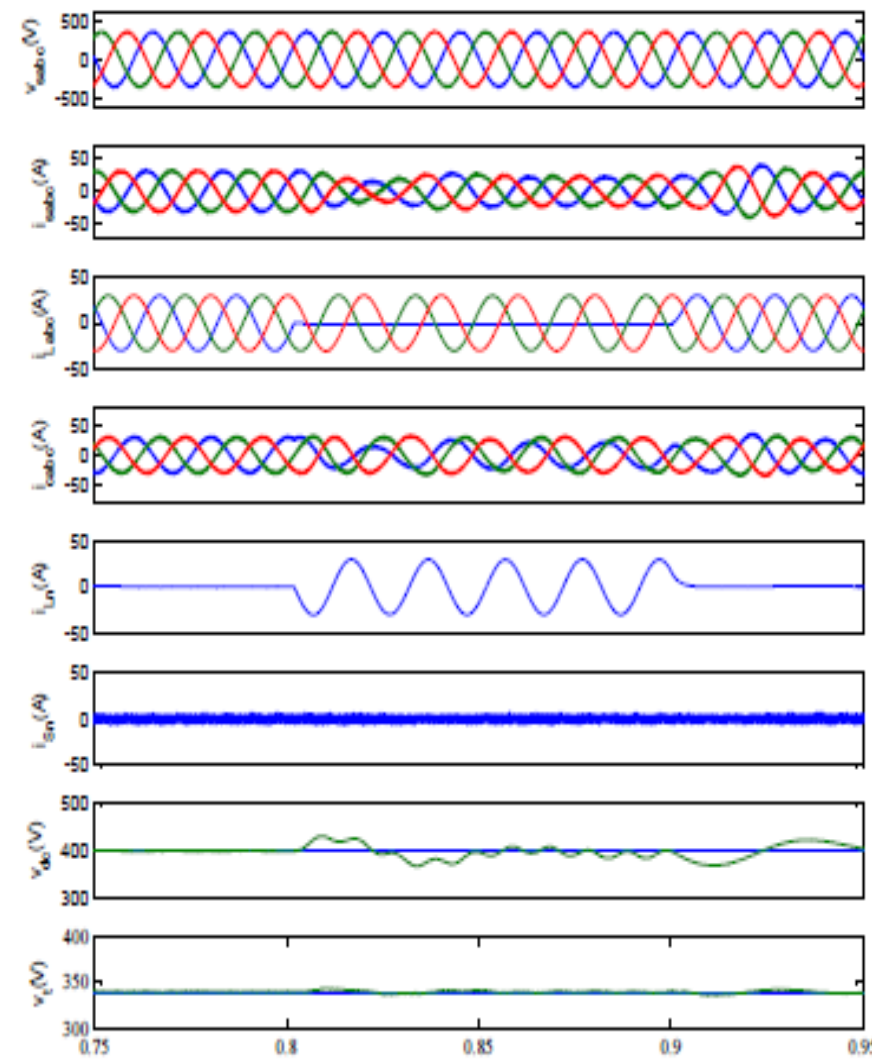

Fig.3 Response of peak detection control strategy based STATCOM under linear loads in ZVR mode
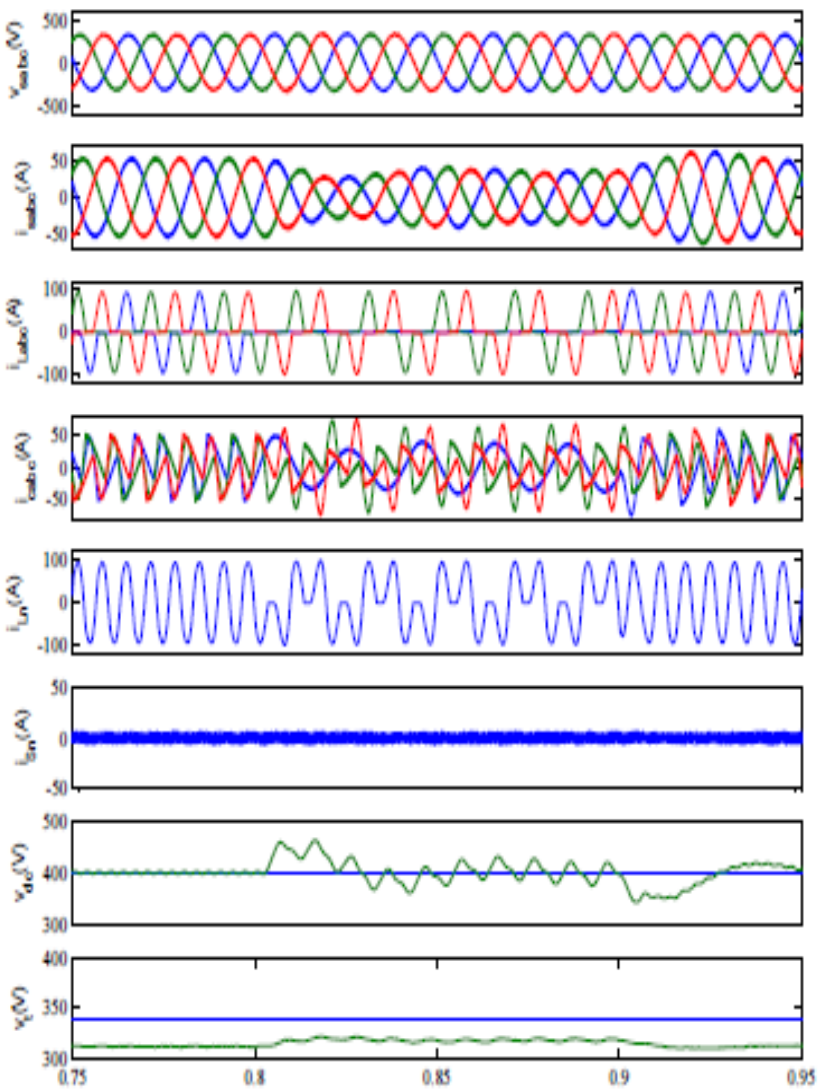

Fig.4 Response of peak detection control strategy based STATCOM under linear loads in PFC mode
5.".
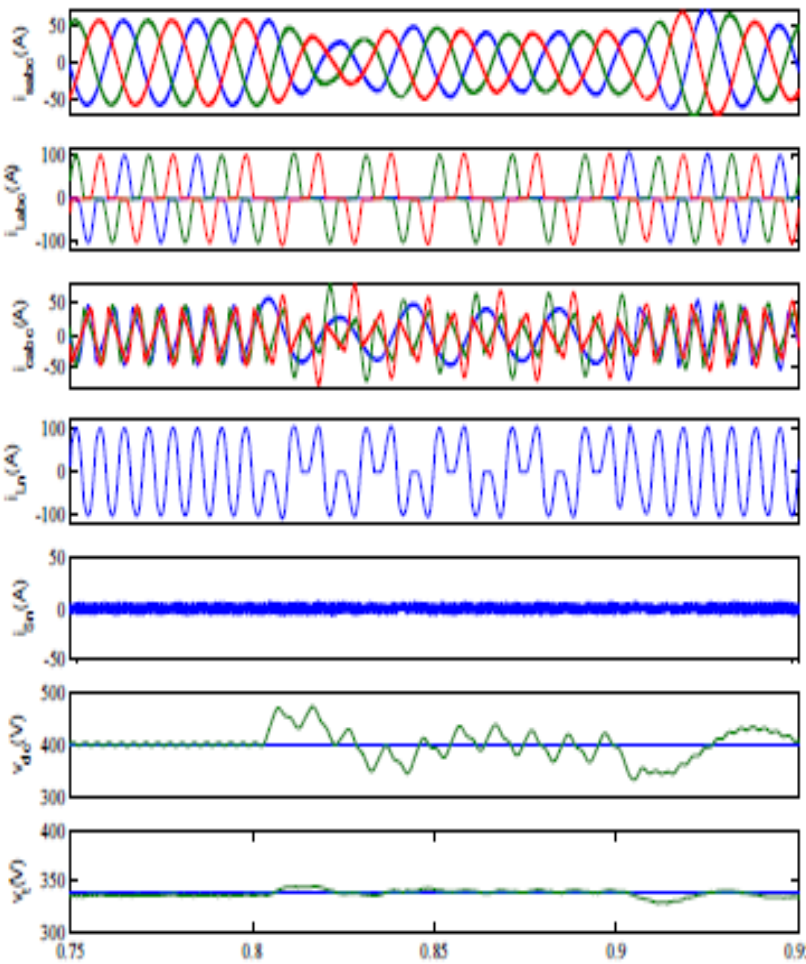

Fig.5 Response of peak detection control strategy based STATCOM under linear loads in ZVRs mode

highly balanced, free from harmonics, the angle between source voltage and source current is zero, source neutral current is maintained to zero. At $\mathrm{t}=0.8 \mathrm{sec}$, one phase is suddenly removed but response parameters of PDN shows highly balanced, free from harmonics, the angle between source voltage and source current is zero, source neutral current is maintained to zero. Again at $\mathrm{t}=0.9 \mathrm{sec}$, disconnected one phase reapplied, it was observed same response as previous in Fig.4. The amplitude of DC bus voltage $\left(\mathrm{v}_{\mathrm{dc}}\right)$ and amplitude of terminal voltage $\left(\mathrm{v}_{\mathrm{tp}}\right)$ are maintained at 400V and 320V in Fig.4.

D. Response of peak detection control strategy based STATCOM under non-linear load in ZVR mode

The response of peak detection control strategy based STATCOM is discussed in ZVR mode at non-linear loads is depicted in Fig.5. The response of PDN parameters are discussed in Fig.5 in terms of source voltage $\left(\mathrm{v}_{\mathrm{sabc}}\right)$, balanced source current $\left(i_{\text {sabc }}\right)$, load current ( $\left.i_{\text {Labc }}\right)$, STATCOM injecting current $\left(i_{c a b c}\right)$, load neutral current of $\operatorname{PDN}\left(\mathrm{i}_{\mathrm{Ln}}\right)$, source neutral current $\left(\mathrm{i}_{\mathrm{Sn}}\right)$, dc bus voltage magnitude $\left(\mathrm{V}_{\mathrm{dc}}\right)$ and amplitude of terminal voltage $\left(\mathrm{v}_{\mathrm{tp}}\right)$ under uni-polar switching operations of STATCOM. Up to $\mathrm{t}=0.8 \mathrm{sec}$, it was clearly observed from Fig. 5 that the source voltage $\left(\mathrm{v}_{\text {sabc }}\right)$ and source current $\left(\mathrm{i}_{\text {sabc }}\right)$ are highly balanced, free from harmonics, reactive power control, source neutral current is maintained to zero. At $\mathrm{t}=0.8 \mathrm{sec}$, one phase is suddenly removed but response parameters of PDN shows highly balanced, free from harmonics, reactive power control, source neutral current is 
maintained to zero. Again at $\mathrm{t}=0.9 \mathrm{sec}$, disconnected one phase reapplied, it was observed same. The amplitude of DC bus voltage $\left(\mathrm{v}_{\mathrm{dc}}\right)$ and amplitude of terminal voltage $\left(\mathrm{v}_{\mathrm{tp}}\right)$ are maintained at $400 \mathrm{~V}$ and $339 \mathrm{~V}$ in Fig.5. Harmonic spectra of proposed STATCOM is shown in Fig.6 and during this condition fundamental source voltage $\left(\mathrm{V}_{\mathrm{sa}}\right)$ is $349.6 \mathrm{~V}$ and its THD is $2.28 \%$, fundamental source current $\left(\mathrm{i}_{\mathrm{sa}}\right)$ is $50.63 \mathrm{~A}$ and THD is $2.64 \%$ whereas fundamental load current $\left(\mathrm{i}_{\mathrm{La}}\right)$ is $48.98 \mathrm{~A}$ and $\mathrm{THD}$ is $91.85 \%$

\section{Conclusion}

The proposed peak detection control strategy based STATCOM has been implemented using MATLAB $\mathrm{R} 2013 \mathrm{~b}$ in power distribution system. The peak detection control strategy used for extracting the active and reactive components at fundamental of load currents. These
[5] H.-L. Jou, K.-D.Wu, J.-C.Wu, andW.-J.Chiang, "A three-phase four-wire power filter comprising a three-phase three-wire active filter and a zig-zag transformer," IEEE Trans. Power Electron., vol. 23, no. 1, pp. 252-259, Jan. 2008.

B. Singh, P. Jayaprakash, T.R. Somayajulu, D.P. Kothari, A. Chandra and K. Al-Haddad, "Integrated three-leg VSC with a zigzag transformer based three-phase four-wire DSTATCOM for power quality improvement," in Proc. of 34th Annual Conference of IEEE Industrial Electronics, 2008, pp.796-801.

[6] B. Singh, V. Garg, and G. Bhuvaneswari, "A novel T-connected autotransformer-based 18-pulse AC-DC converter for harmonic mitigation in adjustable-speed induction-motor drives," IEEE Trans. Ind. Electron., vol. 54, no. 5, pp. 2500-2511, Oct. 2007.

[7] S. Leng, II-Yop Chung, C.S. Edrington and D.A. Cartes, "A new harmonic distortion measurement algorithm for power quality evaluation and compensation," IEEE Power and Energy Society General Meeting, 2011, pp.1-8.

LorenzoMarconi, Fabio Ronchi and Andrea Tilli,"Robust nonlinear control of shunt active filters for harmonic current compensation,"Journal of Automatica, vol. 43, pp. 252-263, 2007

[8] K. Vardar, E. Akpınar and T. Surgevil, "Evaluation of reference current

extraction methods for DSP implementation in active power
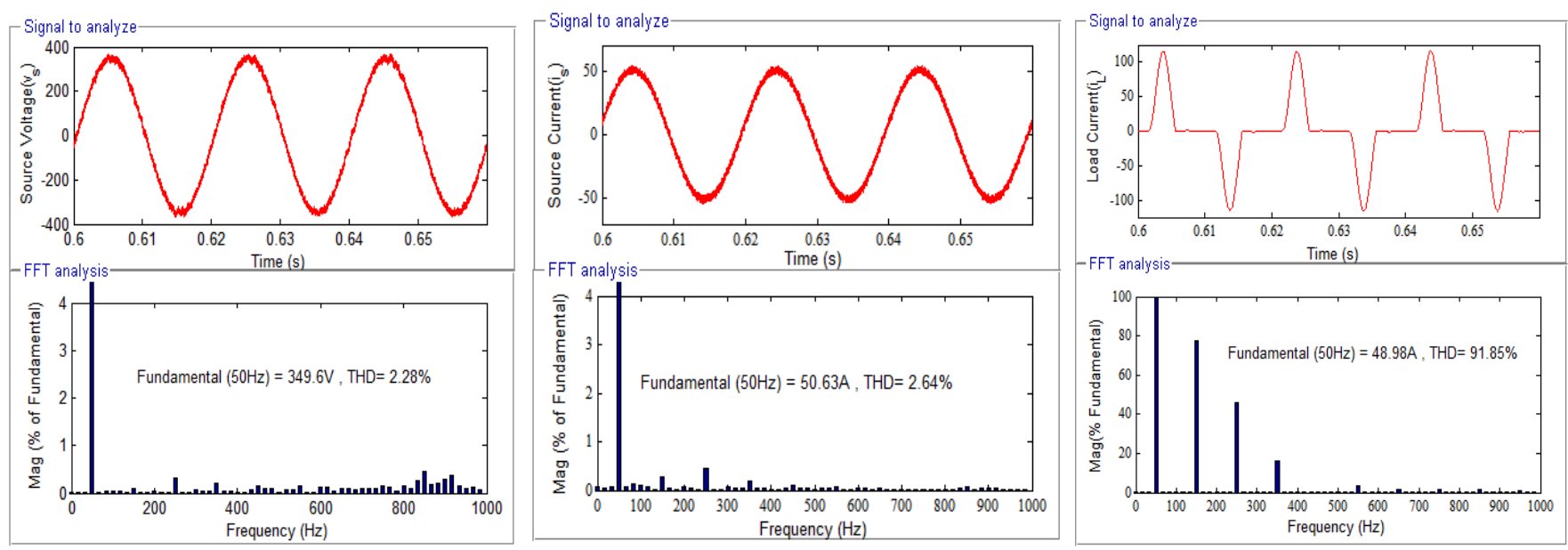

Fig. 6 Harmonic spectra of source voltage, source current and load current

currents, DC bus voltage and PCC voltage are used estimation of reference source currents. The performance of STATCOM gives satisfactory results in MATLAB for suppression of harmonics, PFC at source, reactive power control, load balancing and mitigate neutral current as per PQ standards. The dc bus voltage and PCC voltage are maintained zero overshoot even for small and large disturbances in the load.

\section{References}

[1] Ali Emadi, Abdolhosein Nasiri and Stoyan B. Bekiarov, Uninterruptible Power Supplies and Active Filters, CRC Press, New York, 2005

[2] R. C. Dugan, M. F. Mc Granaghan and H. W. Beaty, "ElectricPower Systems Quality", 2ed Edition, McGraw Hill, New York,2006.

[3] Pericle Zanchetta, Mark Sumner, Maria Marinelli, Francesco Cupertino,

"Experimental modeling and control design of shunt active power filters," Journal of Control Engineering Practice, vol. 17, pp. 11261135, 2009.

[4] Yu-Jen Liu, G.W. Chang, Rong-Chin Hong and Chi Yun Chao, "Applications of real-time simulation techniques for shunt active power filter design," in Proc. of IEEE Power and Energy Society General Meeting, 2009, pp.1-5. filters," Journal of Electric Power Systems Research, vol. 79, pp. $1342-1352$,

2009.

[9] R. Singh, A.K. Singsh and P. Kumar, "Comparison of three evolutionary

algorithms for harmonic mitigation using SAPF," in Proc. of 6th IEEE

International Conference on Industrial and Information Systems, 2011, pp.392-397.

[10] Electromagnetic Compatibility (EMC)—Part 3: Limits-Section 2:Limits for Harmonic Current Emissions (Equipment Input Current $>16$ A per Phase) IEC1000-3-2 Document1st ed. , (1995)

[11] IEEE Recommended Practices and requirement for Harmonic Control on Electric Power System, IEEE Std.519, 1992.

An Luo, Lu Fang, Xianyong Xu, Shuangjian Peng, Chuanping Wu and Houhui Fang, "New control strategy for DSTATCOM without current sensors and its engineering application,"Journal of Electrical Power and Energy Systems, vol. 33, pp. 322-331, 2011. A. Ghosh and G. Ledwich, Power Quality Enhancement using Custom Power Devices, Springer International Edition, Delhi, 2009.

[12] Cardenas, V., Moran, L., Bahamondes, A., Dixon, J.: 'Comparative analysis of real time reference generation techniques for four-wire shunt active power filters'. Proc. IEEE 34th Annual Power Electronics Specialist Conf., 2003, vol. 2, pp. 791-796 